\title{
The effects of a community-based disaster drill of simulating Disaster Medical Assistance Team (DMAT) on the knowledge and attitudes
}

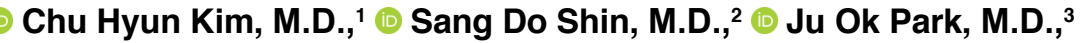 \\ (1) Seong Chun Kim, M.D., ${ }^{4}$ 낭 Phillip L Coule, M.D. ${ }^{5}$
}

\begin{abstract}
1Department of Emergency Medicine, Inje University College of Medicine, Seoulpaik Hospital, Seoul-Korea
${ }^{2}$ Department of Emergency Medicine, Seoul National University College of Medicine, Seoul National University Hospital, Seoul-Korea

${ }^{3}$ Department of Emergency Medicine, Hallym University College of Medicine, Dongtan Sacred Heart Hospital, Hwaseong-Korea

${ }^{4}$ Department of Emergency Medicine, Gyoungsang National University College O of $\mathrm{f}$ Medicine, Gyoungsang National University Hospital,

Gyoungsang-Korea

${ }^{5}$ Department of Emergency Medicine, Medical College of Georgia, Augusta University, Augusta-United States
\end{abstract}

\begin{abstract}
BACKGROUND: We evaluated the effects of community-based disaster drill of simulating disaster medical assistance team on the knowledge and the attitudes.

METHODS: Eight hours disaster drills, including didactic lectures, table simulation, and outdoor field simulation, were developed for participants who were recruited from community health centers, emergency departments, fire stations, emergency medical technicians' academy, and emergency information center in the Seoul Metropolitan City area from 2006 to 2008 . We surveyed on the knowledge and the attitude using designed questionnaire before and after drill. We compared changes using t-test and repeated measure ANOVA.
\end{abstract}

RESULTS: In this study, 14 community-based drills were performed and 525 (79.4\%) people responded to both pre- and post-drill survey. Of these, the doctor was the second common occupation $(26.9 \%)$ after volunteer students $(47.1 \%)$. Overall, knowledge and attitude score significantly increased from $3.9 \pm 1.0$ to $4.3 \pm 0.9$ ( $p<0.00 \mathrm{I}$ ) and from $21.4 \pm 3.4$ to $22.4 \pm 3.2$ ( $p<0.00 \mathrm{I}$ ), respectively. The difference among professional license groups between pre- and post-drill knowledge level was significant $(p=0.03)$, while the difference among jobs for attitude between pre- and post-drill was not different $(p=0.78)$.

CONCLUSION: Disaster drills on the establishment and operation of DMAT may affect both knowledge and attitude of participants positively.

Keywords: Community networks; disaster; DMAT; education; effect.

\section{INTRODUCTION}

Currently, there have been several disasters, including the Sarin gas attack, the terrorist attacks of September II, 200 I, anthrax bioterrorism incidents, sudden Acute Respiratory Syndrome (SARS), and repeating natural disasters. ${ }^{[1-3]}$ Their incidence and severity are increasing so that they have signif- icant impact on not only human mortality and morbidity but also socioeconomic coast..$^{[4,5]}$

Well trained, competent, and responsive public health work forces are needed to respond the emergencies in timely manners and provide the essential public health service. Adequate preparedness of the regional healthcare workforce can be

Cite this article as: Kim CH, Shin SD, Park JO, Kim SC, Coule PL. The effects of a community-based disaster drill of simulating Disaster Medical Assistance Team (DMAT) on the knowledge and attitudes. Ulus Travma Acil Cerrahi Derg 2021;27:174-179.

Address for correspondence: Chu Hyun Kim, M.D.

85, 2-ga, Jeo-dong, Jung-gu, Seoul 100-032, Korea Seoul - South Korea

Tel: +82 2-2270-0II9 E-mail: juliannnn@hanmail.net

Ulus Travma Acil Cerrahi Derg 2021;27(2):174-179 DOI: 10.14744/tjtes.2020.93947 Submitted: 02.03.20I8 Accepted: 05.04.2020

Copyright 2021 Turkish Association of Trauma and Emergency Surgery 
achieved through a steady effort to train, educate, and evaluate. To meet that effort, well organized community-based disaster drill where different regional occupational health professionals can be participated is essential.

Thus, it is important for the participants in the disaster drills to have not only exact knowledge but also an appropriate attitude about the establishment and operation of a community-based Disaster Medical Assistance Team (DMAT) using regional available resources.

The community-based disaster drills can encourage the participants to understand what their roles are and what they should prepare. However, it is not easy to take the consecutive and adherent community-based disaster drill because of requiring resources. ${ }^{[6]}$ To repeat the community-based disaster drill continuously, the drill should be effective for participants. From this viewpoint, the Seoul Metropolitan City government requested the maintainable and effective community-based disaster drill model to prepare an emerging threat as a regional disaster planning. Therefore, we developed the community-based disaster drill simulation model and evaluated the effects of disaster drill on the knowledge and the attitude of eligible members to participate in the community-based simulation of DMAT.

\section{MATERIALS AND METHODS}

This study was exempted from the approval process by the Institutional Review Board of the study institution.

\section{Study Design}

Study design was a before and after observation and surveillance study using a questionnaire.

\section{Study Setting and Participants}

The city of Seoul is the capital of the Republic of Korea (South Korea) and has a land area of $605.3 \mathrm{Km}^{2}$ and a population of 10.4 million. The city has 25 autonomous districts (like a county in the US). Each district has one community health center $(\mathrm{CHC})$ that provides primary health care and community health planning. Seoul has 56 Emergency Departments (EDs) (one level I ED and 30 level 2 EDs, and 25 level 3 EDs) for emergency care. An emergency information center provides medical advice and pre-arrival instructions for emergency calls and coordinates the hospital emergency resources, 25 police agencies, and 23 EMS agencies with emergency ambulance stations operated by the fire department. These agencies are tasked with the primary medical response during disasters. ${ }^{[7,8]}$

Routine emergency medical service is provided by a fire-based EMS system, but the Disaster Management Act designated the Community Health Center as the entity responsible for coordinating disaster preparedness and response activities.
During a disaster response, each emergency department provides human resources and supplies for disaster response. Level I EDs deploy their DMAT facility, ambulances, basic equipment, and material for emergency field care with a standardized personnel compliment (six ED physicians, four nurses, six technicians). Level 2 and 3 EDs deploy the ambulance for transport and a standardized staff (one physician, one nurse, one technician). The Emergency Information Center tracks and reports resource availability, including available intensive care units, operating rooms, and surgical subspecialty availability in the hospitals to the DMAT in the field. The Fire based-EMS is responsible for the rescue, initial care and transportation to either the DMAT or the hospital. Effective disaster response by the DMAT requires its members to be well trained and knowledgeable about their role during the disaster event.

\section{Development of Disaster Drill Protocol}

In October 2005, experts on disaster medicine, EMS physicians, fire department officials, and community health authority officials developed the DMAT drill prototype:

I. Explosion of unclear etiology (intentional or accidental). ${ }^{[9]}$

2. Participating institutions are three PHCs, one level I ED, all level 2 and level 3 EDs under each participating PHC in three districts (3-5 level 2 ED and 3-5 level 3 EDs), one emergency information center, and three EMS agencies operated by the fire department.

3. Number of patients was a minimum of 25 .

4. A minimum of 10 ambulances for transport was recruited from three community health centers, all EDs, and the three fire departments participating in this drill.

5. Rescue was performed by firefighters.

6. Safety was the responsibility of the district police department.

7. EMT students were used as mock patients except several manikins for emergency procedures.

The training and exercise program consisted of eight hours, one day as follows:

I. Pre-course evaluation (15 minutes)

2. Two didactic lecture session (every 45 minutes, total 90 minutes) on the general concept of disaster preparedness (Ist session) and DMAT activity ( ${ }^{\text {nd }}$ session)

3. One table-top simulation (30 minutes)

4. Field drill (240 minutes)

5. Debriefing session (30 minutes)

6. Post-course evaluation ( 15 minutes)

The first didactic session was composed of the following subjects: the concept of disaster response, disaster epidemiology, disaster-related Acts, composition and operation of DMAT, incident command system, and hospital disaster preparedness. The second didactic session was composed of 
safety and scene security, triage, basic and advanced trauma life support in DMAT activity, evacuation and transport, communication, and support for DMAT activity. ${ }^{[10,11]}$

The table-top simulation focused on the roles of the DMAT team members. The DMAT was composed of five section teams including a Triage Team (I doctor and I nurse or I EMTs), a Treatment Team (5 to 8 doctors and nurses), a Transport Team (5 to 8 EMTs or general physicians and 5-8 drivers), a Communication Team (three communication technicians), and a Supporting Team (4-6 nurses). Rescue and safety were performed by fire department. Security was provided by a police detachment assigned to the DMAT. Each exercise was facilitated and the teams performed the table top exercise before the field simulation. The range of the number of DMAT team members participating was 25-35 per exercise.

In the field simulation, 25 EMT students were moulaged with various injuries consistent with the scenario. Cards describing the victim's injuries were attached to each patient. Basic vital signs, mental status, as well as the main injury were recorded on the card. Communication was facilitated via two way handheld radio.

Patients were evacuated from the scene by the fire department without triage or treatment and were delivered to the triage sector. Patients were triaged based on a modified Simple Triage and Rapid Transport (START): most urgent, urgent, non-urgent, and delayed. ${ }^{[2]}$ The triaged patients were moved to the field hospital and managed on the basis of the ATLS guidelines. ${ }^{[13]}$ After initial management and stabilization, the patients were moved to the ambulances. Once loaded -further transport, receiving and further communications regarding the patient were simulated.

\section{Outcomes}

We performed a pre- and post-evaluation for the same subjects using a questionnaire before and after the training and drill. Questionnaire had five topics, including response to disasters, patient triage, disaster preparedness, disaster effects, and pre-hospital trauma care. Another five questions concerned the responders' attitude concerning disaster response, including individual decision making for disaster preparedness, institutional role, education and training, community-based DMAT simulations, and their individual role in disaster (Appendix I). Each opinion item has ranked on a I to 5 scale. Therefore summation of each item on knowledge and attitude ranged from 5 to 25 points. The higher score, the better active attitude is.

\section{Primary Analysis}

We compared the changes between pre-drill and post-drill on the knowledge and attitude on disaster using the paired t-test. We also compared the specific subgroup difference ac- cording to professional license group (=job) using the repeated measure ANOVA. The statistical significance was defined when the $p$-value was less than 0.05 .

\section{RESULTS}

\section{Demographic Findings of Study Participants}

In this study, 14 disaster drills of community-based simulation of DMAT from 2006 to 2009 were enrolled. Total 525 (79.4\%) people were responded to both pre- and post-evaluation survey and they were recruited from 14 PHCs, 54 EDs, four fire departments, and one emergency information center, and 3 EMT schools. Table I shows the demographic findings of disaster drills and respondents. Male was $44.8 \%$, and the median age was 25 years old (range, 19-6I). Institution demographics was 25 (4.8\%) from primary health care centers, 26 (5.0\%) from fire departments, and 227 (43.3\%) from emergency departments. Doctor was the second common occupation (26.9\%) after volunteer students (47.1\%).

Table I. Demographic findings of community-based disaster drill and respondents

\begin{tabular}{|c|c|c|}
\hline \multirow[t]{2}{*}{ Variables } & \multicolumn{2}{|c|}{ Value } \\
\hline & $\mathbf{n}$ & $\%$ \\
\hline Total & 525 & \\
\hline Male & 235 & 44.8 \\
\hline Age, median (range) & \multicolumn{2}{|c|}{$25(|9-6|)$} \\
\hline \multicolumn{3}{|l|}{ Institution } \\
\hline Primary health care center & 25 & 4.8 \\
\hline Fire station & 26 & 5.0 \\
\hline Emergency medical technician academy & 247 & 47.1 \\
\hline Level I emergency department & 106 & 20.2 \\
\hline Level 2 emergency department & 76 & 14.5 \\
\hline Level 3 emergency department & 45 & 8.6 \\
\hline \multicolumn{3}{|l|}{ Occupation } \\
\hline Emergency medical technician & 14 & 2.7 \\
\hline Nurse & 81 & 15.4 \\
\hline Doctor & $|4|$ & 26.9 \\
\hline Administrative personnel & 42 & 8.0 \\
\hline Student & 247 & 47.1 \\
\hline \multicolumn{3}{|l|}{ Drill by year } \\
\hline Total & 14 & \\
\hline 2006 & 4 & \\
\hline 2007 & 2 & \\
\hline 2008 & 4 & \\
\hline 2009 & 4 & \\
\hline \multicolumn{3}{|l|}{ Number of respondent per each } \\
\hline drill, median (range) & \multicolumn{2}{|c|}{$39(14-58)$} \\
\hline
\end{tabular}


Table 2. Overall comparison between pre- and post-course for knowledge and attitude for disaster preparedness

\begin{tabular}{|c|c|c|c|c|c|c|c|c|}
\hline \multirow[t]{2}{*}{ Items } & \multicolumn{2}{|c|}{ Pre-evaluation (a) } & \multicolumn{2}{|c|}{ Post-evaluation (b) } & \multicolumn{2}{|c|}{ Difference (b-a) } & \multirow[t]{2}{*}{$t$ value } & \multirow[t]{2}{*}{ p-value ${ }^{* * *}$} \\
\hline & Mean & Std & Mean & Std & Mean & $95 \% \mathrm{Cl}$ & & \\
\hline Knowledge* & 3.9 & 1.0 & 4.3 & 0.9 & 0.4 & $0.3-0.5$ & 8.9 & $<0.0001$ \\
\hline Attitude ${ }^{* *}$ & 21.4 & 3.4 & 22.4 & 3.2 & 1.0 & $0.8-1.3$ & 8.3 & $<0.0001$ \\
\hline
\end{tabular}

"Score for Knowledge is from I (least) to 5 (greatest). ${ }^{* *}$ Score for Attitude is from 5 (least) to 25 (greatest). ${ }^{* * *}$ The p-value was measure by paired t-test.

\section{Main Outcomes}

Table 2 shows the overall difference between pre- and postcourse. Overall, knowledge and attitude score significantly increased from $3.9 \pm 1.0$ to $4.3 \pm 0.9(p<0.001)$ and from $21.4 \pm 3.4$

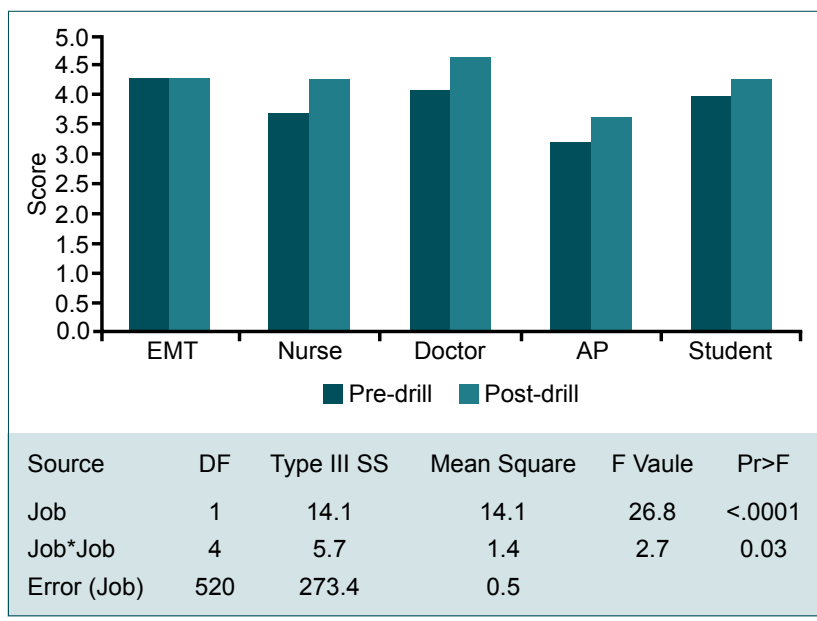

Figure 1. Comparison of knowledge between pre-drill and postdrill among job of respondents and summary statistics by the repeated measure ANOVA. There was a significant difference among jobs $(p=0.03)$. EMT: Emergency medical technicians; AP: Administrative professionals.

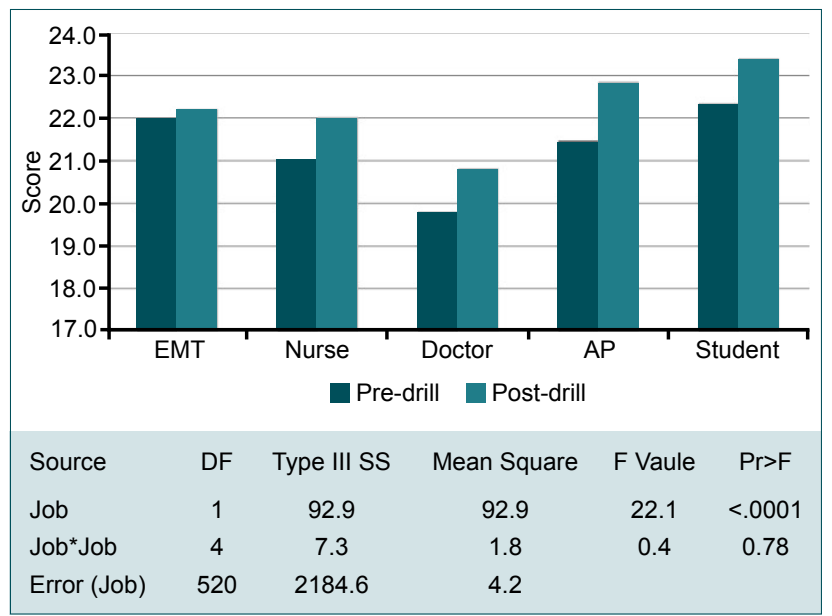

Figure 2. Comparison of attitude between pre-drill and post-drill among job of respondents and summary statistics by the repeated measure ANOVA. There was no significant difference among jobs $(p=0.78)$. EMT: Emergency medical technicians; AP: Administrative professionals. to $22.4 \pm 3.2(p<0.001)$, respectively. Overall significant increase in knowledge and attitude was found in this survey.

Fig. I shows the difference among professional license groups between pre- and post-drill knowledge level. There was a significant difference among jobs $(p=0.03)$. Emergency medical technicians showed little difference compared to other groups. Fig. 2 shows the difference among jobs for attitude between pre- and post-drill. There was no significant difference among jobs $(p=0.78)$.

\section{Limitations}

We modeled a one-day (8 hours course) using a man-made disaster scenario, which is very different from special disaster, such as radiologic or nuclear, chemical, or biologic events, to be generalized. This survey was done before and immediately after drill. Therefore, very short-term effect by the community-based disaster drill should be considered.

Designed questionnaire was very simple with five items for knowledge and five items for attitude. To evaluate the exact effect on the knowledge and attitude, much more aspects should be surveyed.

\section{DISCUSSION}

We developed the community-based DMAT drill. This kind of drill has been invented and used for many communities. ${ }^{[14-16]}$ However, DMAT drill cannot be the same among communities because the EMS system, hospital resources, and disaster acts or legislation for the incident commander system are very different. We reviewed the disaster drill protocol like the NDLS-Advance life Support course. ${ }^{\left[{ }^{[7]}\right.}$ We also compared the triage tool among disaster drill recommended. ${ }^{[18]}$ Size and number of DMAT were discussed on the basis of the environment of Seoul metropolitan city. The very huge DMAT in the US or the very small DMAT in Japan was not fit for this setting. ${ }^{[19,20]}$ Each community has their own proper size of DMAT according to the mission.

Our DMAT was composed of 25 to 35 professional and supporting members in five sector teams. This size is medium compared to Japan's or USA's team. We selected the explosive and man-made disaster as a principle scenario, which was very high likely to occur concerning the epidemiologic ap- 
proach. In the past, we had several explosive and man-made disasters. ${ }^{[21,22]}$ Although the terrorist attack or chemical disaster would come to our community, the traditional disaster scenario would be much more fitted for our community.

In this study, overall knowledge and attitude of participants significantly increased. Several studies have shown the similar result of the effectiveness of disaster drill. ${ }^{[23-27]}$ In these previous studies, EMTs, public health personnel, local administrative officials, and local volunteers were not enrolled, who play a crucial role in disaster response and collaboration with hospital medical staffs. In addition, the training programs did not contain field stimulation but used didactic lectures, computer-based website education, and so on. Through field stimulation, participants can experience and actively take part in the establishment and operation of community-based DMAT. If they can have the chance of repeated training, their physical skills and knowledge, as well as attitude, would be improved. Idrose et al. ${ }^{[28]}$ reported that stimulation in the classroom could be a complementary form of disaster training that is cost-effective, relatively easy to conduct, comprehensive, effective and acceptable. Any form of stimulation of disaster training may be better than no stimulation program in disaster training.

The method to assess the effects of disaster drill in this study was pre- and post-evaluation like other studies. ${ }^{[29,30]}$ The questionnaire on pre- and post-evaluation was identical. We did not test the reliability and validity of this questionnaire, which should be determined, although this questionnaire was very common in education research. The systematic tools to assess the effects of training should be further developed so that evidence-based disaster planning and training could be initiated. ${ }^{[31,32]}$

Between pre- and post-drill survey, we could find a significant increase of knowledge and attitude. Most of the attendees had no experience in disaster drill. Therefore, the effect was much more from the community-based disaster drill. However, there were statistically significant differences among professional license groups. In particular, emergency medical technicians showed a minimal difference between pre- and post-drill compared to other groups, while no significant difference was there in attitude. These features can encourage us to develop and implement more customized training for disaster responders.

\section{Conclusion}

We modeled the community-based DMAT drill in conjunction with the Seoul city government. All institutions, including public health authorities, hospitals, EMS agencies, and fire and police department, participated in this active drill for four years. When we evaluated the attitude and knowledge of participants, community-based DMAT drill showed a very good educational effect in an explosive and man-made disaster scenario.

\section{Acknowledgement}

This work was supported by a grant from Research year of Inje University in 2016.

Ethics Committee Approval: This study was exempted on the approval process by the Institutional Review Board of study institution.

Peer-review: Internally peer-reviewed.

Authorship Contributions: Concept: C.H.K., S.D.S.; Design: C.H.K., S.D.S.; Supervision: C.H.K., S.D.S.; Resource: J.O.P., S.C.K.; Materials: J.O.P., S.C.K.; Data: C.H.K., J.O.P., S.C.K.; Analysis: C.H.K., S.D.S., J.O.P.; Literature search: C.H.K., J.O.P., S.C.K.; Writing: C.H.K., S.D.S., P.L.C.; Critical revision: C.H.K., P.L.C.

Conflict of Interest: None declared.

Financial Disclosure: The authors declared this study has received financial support by Seoul Metropolitan City Government.

\section{REFERENCES}

1. Centers for Disease Control and Prevention(CDC). Deaths in World Trade Center terrorist attacks: New York City, 2001. Morb Mortal Wkly Rep 2002;51:16-8.

2. Centers for Disease Control and Prevention (CDC). Update: Investigation of bioterrorism-related anthrax and interim guidelines for clinical evaluation of persons with possible anthrax. MMWR Morb Mortal Wkly Rep 2001;50:941-8.

3. Bush LM, Abrams BH, Beall A, Johnson CC. Index case of fatal inhalational anthrax due to bioterrorism in the United States. N Engl J Med 2001;345:1607-10. [CrossRef]

4. Disaster medical response research: a template in the Utstein style. Task Force on Quality Control of Disaster Management. Prehosp Disaster Med 1996;11:82-90. [CrossRef]

5. Sundnes KO. Health disaster management: guidelines for evaluation and research in the Utstein style: executive summary. Task Force on Quality Control of Disaster Management. Prehosp Disaster Med 1999;14:43-52. [CrossRef]

6. Simpson DM. Earthquake drills and simulations in community-based training and preparedness programmes. Disasters 2002;26:55-69. [CrossRef]

7. Act on Natural Disaster Mitigation Measures. Available at: http://www. moleg.go.kr/. Accessed January 19, 2010.

8. Act on Disaster and Safety Management. Available at: http://www.moleg.go.kr/. Accessed January 19, 2010.

9. Janing J. Assessment of a scenario-based approach to facilitating critical thinking among paramedic students. Prehosp Disaster Med 1997;12:215-21. [CrossRef]

10. De Grace M, Ericson D, Folz H, Greene W, Ho K, Pearce L. Proceedings for the 5th Asia-Pacific Conference on Disaster Medicine: creating an agenda for action. Prehosp Disaster Med 2001;16:18-21. [CrossRef]

11. Born CT, Briggs SM, Ciraulo DL, Frykberg ER, Hammond JS, Hirshberg A, et al. Disasters and mass casualties: I. General principles of response and management. J Am Acad Orthop Surg 2007;15:388-96.

12. Benson M, Koenig KL, Schultz CH. Disaster triage: START, then SAVE--a new method of dynamic triage for victims of a catastrophic earthquake. Prehosp Disaster Med 1996;11:117-24. [CrossRef]

13. Collicott PE, Hughes I. Training in advanced trauma life support. JAMA 1980;243:1156-9. [CrossRef]

14. Sweeney B, Jasper E, Gates E. Large-scale urban disaster drill involving 
an explosion: lessons learned by an academic medical center. Disaster Manag Response 2004;2:87-90. [CrossRef]

15. Wise GI. Preparing for disaster: a way of developing community relationships. Disaster Manag Response 2007;5:14-7. [CrossRef]

16. Lifshitz I, Adler J, Katz J. Model for preparedness of a public institution for a terrorist attack. Prehosp Disaster Med 2008;23:467-71. [CrossRef]

17. Coule PL, Schwartz RB. The national disaster life support programs: a model for competency-based standardized and locally relevant training. J Public Health Manag Pract 2009;15:S25-30. [CrossRef]

18. Jenkins JL, McCarthy ML, Sauer LM, Green GB, Stuart S, Thomas TL, et al. Mass-casualty triage: time for an evidence-based approach. Prehosp Disaster Med 2008;23:3-8. [CrossRef]

19. Henderson AK, Lillibridge SR, Salinas C, Graves RW, Roth PB, Noji EK. Disaster medical assistance teams: providing health care to a community struck by Hurricane Iniki. Ann Emerg Med 1994;23:726-30.

20. Edasawa H. First aid station set up in Okujiri Island after earthquake and tidal wave disasters in July, 1993. [Article in Japanese]. Kango 1993;45:74-81.

21. Park DK, Park KH, Ko JS, Kim YS, Chung NE, Ahn YW, et al. The role of forensic anthropology in the examination of the Daegu subway disaster (2003, Korea). J Forensic Sci 2009;54:513-8. [CrossRef]

22. You KC, Ahn ME, Cho YJ, Chaeng JM, Lim KS. Injury Type in Sampung Collapse. [Article in Korean]. J Korean Soc Emerg Med 1997;8:185-92.

23. Beaton RD, Johnson LC. Beaton RD, Johnson LC. Instrument development and evaluation of domestic preparedness training for first responders. Prehosp Disaster Med 2002;17:119-25. [CrossRef]

24. Chung S, Mandl KD, Shannon M, Fleisher GR. Efficacy of an educa- tional Web site for educating physicians about bioterrorism. Acad Emerg Med 2004;11:143-8. [CrossRef]

25. Qureshi KA, Gershon RR, Merrill JA, Calero-Breckheimer A, Murrman $\mathrm{M}$, Gebbie KM, et al. Effectiveness of an emergency preparedness training program for public health nurses in New York City. Fam Community Health 2004;27:242-9. [CrossRef]

26. Risavi BL, Salen PN, Heller MB, Arcona S. A two-hour intervention using START improves prehospital triage of mass casualty incidents. Prehosp Emerg Care 2001;5:197-9. [CrossRef]

27. Olness K, Sinha M, Herran M, Cheren M, Pairojkul S. Training of health care professionals on the special needs of children in the management of disasters: experience in Asia, Africa, and Latin America. Ambul Pediatr 2005;5:244-8. [CrossRef]

28. Idrose AM, Adnan WA, Villa GF, Abdullah AH. The use of classroom training and simulation in the training of medical responders for airport disaster. Emerg Med J 2007;24:7-11. [CrossRef]

29. Harrington SS, Walker BL. Is computer-based instruction an effective way to present fire safety training to long-term care staff?. J Nurses Staff Dev 2003;19:147-54. [CrossRef]

30. Parrish AR, Oliver S, Jenkins D, Ruscio B, Green JB, Colenda C. A short medical school course on responding to bioterrorism and other disasters. Acad Med 2005;80:820-3. [CrossRef]

31. Auf der Heide E. The importance of evidence-based disaster planning. Ann Emerg Med 2006;47:34-49. [CrossRef]

32. Burstein JL. The myths of disaster education. Ann Emerg Med 2006;47:50-2. [CrossRef]

\section{ORIJINAL ÇALIŞMA - ÖZET}

\section{Acil tıbbi yardım ekibi simülasyonunun toplum-temelli afet tatbikatında bilgi ve tutumlar üzerindeki etkileri \\ Dr. Chu Hyun Kim, ${ }^{1}$ Dr. Sang Do Shin, ${ }^{2}$ Dr. Ju Ok Park, ${ }^{3}$ Dr. Seong Chun Kim, ${ }^{4}$ Dr. Phillip L Coule ${ }^{5}$}

${ }^{1}$ Inje Üniversitesi Tıp Fakültesi, Seoulpaik Hastanesi, Acil Tıp Bölümü, Seul-Kore

${ }^{2}$ Seul Ulusal Üniversitesi Tıp Fakültesi, Seul Ulusal Üniversite Hastanesi, Acil Tıp Bölümü, Seul-Kore

${ }^{3}$ Hallym Üniversitesi Tıp Fakültesi, Dongtan Sacred Heart Hastanesi, Acil Tıp Bölümü, Hwaseong-Kore

${ }^{4}$ Gyoungsang Ulusal Üniversitesi Tıp Fakültesi, Gyoungsang Ulusal Üniversite Hastanesi, Acil Tıp Bölümü, Gyoungsang-Kore

${ }^{5}$ Georgia Medikal Kolej, Augusta Üniversitesi, Acil Tıp Bölümü, Augusta-Amerika Birleşik Devletleri

AMAÇ: Acil tıbbi yardım ekibi simülasyonunun toplum-temelli afet tatbikatında bilgi ve tutumlar üzerindeki etkisini değerlendirdik.

GEREÇ VE YÖNTEM: 2006 yılından 2008'e kadar Seul Metropolitan Şehir bölgesindeki toplum sağlı̆̆ı merkezleri, acil servisler, itfaiye istasyonları, acil tıp teknisyenleri akademisi ve acil durum bilgi merkezinden işe alınan katılımcılar için didaktik dersler, masabaşı simülasyonu ve açık alan simülasyonunu içeren sekiz saatlik afet tatbikatları geliştirildi. Tatbikattan önce ve sonra tasarlanmış anketi kullanarak bilgi ve tutum üzerine anket yaptık. Değişiklikleri t-testi ve tekrarlayan ölçüm ANOVA analizi ile karşılaştırdık.

BULGULAR: Çalışma süresince toplam 14 toplum-temelli tatbikat yapılmışır. Hem tatbikat öncesi hem de sonrası ankete 525 (\%79.4) kişi yanıt verdi. Bunların içerisinde doktorluk, gönüllü öğrencilerden (\%47.I) sonra ikinci yaygın meslekti (\%26.9). Genel olarak, bilgi ve tutum puanı sırasıyla $3.9 \pm 1.0^{\prime}$ dan $4.3 \pm 0.9^{\prime}$ a $(p<0.00 I)$ ve $21.4 \pm 3.4^{\prime}$ ten $22.4 \pm 3.2^{\prime} y e(p<0.001)$ anlamlı olarak artmıştı. Mesleki lisans grupları arasında tatbikat öncesi ve sonrası bilgi düzeyi arasındaki fark anlamlıydı $(p=0.03)$, tatbikat öncesi ve sonrası tutum açııından meslekler arasındaki fark ise anlamlı değildi $(p=0.78)$.

TARTIŞMA: Acil Tıbbi Yardım Ekibi'nin kurulması ve işletilmesine ilişkin afet tatbikatı, katılımcıların hem bilgi hem de tutumlarını olumlu etkileyebilir. Anahtar sözcükler: Acil Tıbbi Yardım Ekibi; afet; eğitim; etkinlik; toplum ağları.

Ulus Travma Acil Cerrahi Derg 2021;27(2):174-179 doi: 10.14744/tjtes.2020.93947 
Appendix I. Surveillance questionnaire for pre- and post-evaluation of disaster drill

\section{A. Knowledge items}

I. Which of followings is not the one of principals of Disaster preparedness?

a. Planning prior to the disaster

b. Assessing the hazards

c. Establishment of the communication system

d. Establishment of the automaticity of the disaster respond system

2. Which of followings is not correct about the color tagging of triage system?

a. Yellow: emergent patient who needs rapid treatment in minuets and hours.

b. Red: urgent patient who needs treatment but not in minuets and hours.

c. Green: patient who needs treatment in hours and days.

d. Black: patient who needs cardiopulmonary resuscitation.

3. Which of following is not the one of the rationale of establishment of emergency medical system during the disaster?

a. Prevention of the mildly injured victims from occupying nearest medical resource.

b. Prevention of the severely injured victims from delay of rapid transport and treatment.

c. Establishment of the well organized command system.

d. Provision of the best treatment to all victims regardless of their severity.

4. Which of followings is the correct about the effect and response of disaster?

a. Primary effect of the disaster usually results from the impact of the disaster itself.

b. Secondary effect of the disaster usually results from reoccurrence of the disaster.

c. The response of the disaster should be rapid and timely.

d. The response of the disaster usually ends with rescue, triage, and transportation of victims in the spot of the disaster.

5. Which of followings are situations where the triage of victims should be abandoned? Choose one.

a. Traumatic brain injury

b. Traumatic airway obstruction

c. Arrest

d. Comatose mentality

\section{B. Attitude items}

I. How much willingness do you have if you are asked to participate the response of the disaster when the disaster would happen in your local area?

\begin{tabular}{|c|c|c|c|c|}
\hline$(1)$ & $(2)$ & $(3)$ & $(4)$ & $(5)$ \\
\hline Least active & & & & Most active \\
\hline
\end{tabular}

2. How much do you agree if your department is asked to respond the disaster prior to your routine job when the disaster would happen in your local area?

\begin{tabular}{|c|c|c|c|c|}
\hline$(1)$ & $(2)$ & $(3)$ & $(4)$ & $(5)$ \\
\hline Least active & & & & Most active \\
\hline
\end{tabular}

3. How much willingness do you have if you are asked to practice the disaster drill regularly?

\begin{tabular}{|c|c|c|c|c|}
\hline$(1)$ & $(2)$ & $(3)$ & $(4)$ & $(5)$ \\
\hline Least active & & & & Most active \\
\hline
\end{tabular}

4. How much willingness do you have if you are asked to work in Disaster Medical Assistance Team (DMAT) when the disaster would happen in your local area?

\begin{tabular}{|c|c|c|c|c|}
\hline$(1)$ & $(2)$ & $(3)$ & $(4)$ & $(5)$ \\
\hline Least active & & & & Most active \\
\hline
\end{tabular}

5. How much do you agree if you are asked that you are the important in your department to respond the disaster in timely manner?

\begin{tabular}{|c|c|c|c|c|}
\hline$(1)$ & $(2)$ & $(3)$ & $(4)$ & $(5)$ \\
\hline Least active & & & & Most active \\
\hline
\end{tabular}

